University of Nebraska - Lincoln

DigitalCommons@University of Nebraska - Lincoln

\title{
Identification and Characterization of a New Allele for the Beta Subunit of Follicle-Stimulating Hormone in Chinese Pig Breeds
}

\author{
M. D. Li \\ G. A. Rohrer \\ USDA-ARS \\ T. H. Wise \\ USDA-ARS \\ J. J. Ford \\ USDA-ARS
}

University of Tennessee Medical School

Follow this and additional works at: https://digitalcommons.unl.edu/hruskareports

Li, M. D.; Rohrer, G. A.; Wise, T. H.; and Ford, J. J., "Identification and Characterization of a New Allele for the Beta Subunit of Follicle-Stimulating Hormone in Chinese Pig Breeds" (2000). Roman L. Hruska U.S. Meat Animal Research Center. 228.

https://digitalcommons.unl.edu/hruskareports/228

This Article is brought to you for free and open access by the U.S. Department of Agriculture: Agricultural Research Service, Lincoln, Nebraska at DigitalCommons@University of Nebraska - Lincoln. It has been accepted for inclusion in Roman L. Hruska U.S. Meat Animal Research Center by an authorized administrator of DigitalCommons@University of Nebraska - Lincoln. 
Animal Genetics,

2000, 31, 28-30

M D Li

Department of Pharmacology, University of

Tennessee Medical School, Memphis, TN 38163, USA

G A Rohrer

T H Wise

J J Ford

USDA-ARS, Roman L. Hruska U.S. Meat Animal Research Center, Clay Center, NE 68933, USA

\title{
Identification and characterization of a new allele for the beta subunit of follicle-stimulating hormone in Chinese pig breeds*
}

\author{
M D Li, G A Rohrer, T H Wise, J J Ford
}

\section{Summary}

During evaluation of follicle-stimulating hormone-beta $(F S H B)$ expression in anterior pituitary glands by an RNase protection assay (RPA), the expected fragment of 205 nucleotides at positions 759-963 was not detected in one boar that had moderate plasma and pituitary FSH concentrations. After subcloning and sequencing, mRNA from this boar lacked an 11-bp fragment ( $5^{\prime}$-CATTTGGAAAC- $\left.3^{\prime}\right)$ at nucleotide positions $807-817$ of the $3^{\prime}$-untranslated region ( $3^{\prime}$-UTR, $D$ allele). Wild-type FSHB (WT allele) was present in pituitary RNA and genomic DNA in both Meishan (MS) and White Composite (WC) pigs; whereas the $D$ allele was present only in MS pigs $(P<0 \cdot 01 ; 5 / 6 \mathrm{MS}$ vs. $0 / 6 \mathrm{WC})$. Also, we found the $D$ allele in five other Chinese breeds but absent in ten American Landrace, 11 Yorkshire and 17 Berkshire pigs. Additionally, the $D$ allele had one silent nucleotide change in the coding region plus six, single nucleotide changes in the $3^{\prime}$-UTR.

Keywords: follicle-stimulating hormone beta, breed variation, swine

Follicle-stimulating hormone (FSH) belongs to a family of $\alpha / \beta$ heterodimeric glycoprotein hormones that includes luteinizing hormone, thyroid-stimulating hormone and chorionic gonadotropin. The common $\alpha$-subunit and the $\beta$-subunit for FSH are each encoded by a separate gene. Expression of FSHB in anterior pituitary glands of boars correlates positively with blood and pituitary FSH concentrations (Zanella et al. 1996; Li et al. 1997; Li et al. 1998a). The current investigation was under-

\section{Correspondence: Dr Joe Ford.}

*The mention of names is necessary to report factually on available data; however, the USDA neither guarantees nor warrants the standard of the product, and the use of the same by USDA implies no approval of the product to the exclusion of others that may also be suitable. GenBank accession number: AF134151.

Accepted 21 September 1999 taken to understand the following. Why did a Meishan (MS) $\times$ White composite (WC) boar (no. 8) with moderate plasma FSH concentrations and FSHB mRNA, determined by RIA and RT-PCR, have no fragment corresponding to the expected size of $F S H B$ by an RPA?

Three Chinese pig breeds (MS, Fengjing and Minzhu), a WC line (1/4 Chester White, 1/4 Landrace, 1/4 Large White, and 1/4 Yorkshire) and $\mathrm{MS} \times \mathrm{WC}$ crossbred pigs were randomly selected from populations at US Meat Animal Research Center (Table 1). Additional liver or skin samples were collected from American Landrace, Yorkshire and Berkshire pigs (Table 1). DNA samples of Erhualian, Xiang and Hainan pigs (Table 1) were provided from different farms in the People's Republic of China. Pigs were selected to maximize ancestral diversity.

FSH concentrations were determined in plasma and extracts of anterior pituitary glands (Zanella et al. 1996). Total RNA was isolated from pituitary glands by guanidine isothiocyanate extraction and $\mathrm{CsCl}$ centrifugation (Chirgwin et al. 1979). RNase protection assay was conducted as described previously ( $\mathrm{Li}$ et al. 1997). Sense and antisense porcine $F S H B$ and $\beta$ actin riboprobes were transcribed in the presence of $\left[\alpha-{ }^{32} \mathrm{P}\right]$ UTP with DNA-dependent T7 or SP6 RNA polymerases from the linearized plasmids with EcoRV or HindIII (Li et al. 1997).

In boar no. 8, no fragment corresponding to the expected size was detected by RPA, but a smaller fragment was observed. The RPA with antisense $\beta$-actin riboprobe indicated that RNA had not undergone degradation. This boar had moderate plasma FSH concentrations (236 ng/ $\mathrm{ml})$. Reverse-transcription and amplification of pituitary RNA from boar no. 8 with primers (sense: 5'-ATTTCCATCCCAAACCCC-3'; antisense: 5'-TCACCCATTCTTAGCCCATTTC-3'; $\mathrm{Li}$ et al. 1997) that spanned the protected region of the FSHB revealed an expected band (i.e. $205 \mathrm{bp}$ ) on ethidium bromide stained agarose gel for all males including boar no. 8. Subsequent sequence analysis of three independent clones indicated that an 11-bp fragment $\left(5^{\prime}\right.$ CATTTGGAAAC-3'; nucleotide positions 807817) was deleted from $F S H B$ mRNA of boar no. 
New porcine FSH及 allele

Table 1. Distribution of FSHB alleles in different breeds

\begin{tabular}{lcclll}
\hline Breed & $\mathrm{N}$ & $W T / W T^{*}$ & $W T / D \dagger$ & $D / D$ & $\mathrm{~F}(D)$ allele \\
\hline Meishan & 6 & 1 & 3 & 2 & 0.58 \\
Fengjing & 5 & 2 & 2 & 1 & 0.40 \\
Minzhu & 8 & 3 & 4 & 1 & 0.38 \\
Erhualian & 6 & 2 & 2 & 2 & 0.50 \\
Xiang & 6 & 1 & 3 & 0 & 0.58 \\
Hainan & 6 & 4 & 2 & 0 & 0.17 \\
WC & 6 & 6 & 0 & 0 & 0 \\
Amer. Landrace & 10 & 10 & 0 & 0 & 0 \\
Yorkshire & 11 & 11 & 0 & 0 & 0 \\
Berkshire & 17 & 17 & 0 & 0 \\
\hline
\end{tabular}

${ }^{*} W T$, wild type allele.

$\dagger D$, deleted allele.

8 ( $D$ allele) compared to the reported allele (WT allele; Hirai et al. 1990).

When the amplified RT-PCR products were resolved on denaturing polyacrylamide gels, the frequency of $W T / W T, W T / D$, and $D / D$ was $37.5 \%, \quad 58.3 \%$ and $4.2 \%$, respectively (Fig. 1A). An identical distribution was also obtained from genomic DNA, indicating that the 11-bp deletion was not post-transcriptional modification (Fig. 1B).

Genomic DNA isolated from liver or skin was amplified (Rohrer et al. 1994a) with FSHB sense (5'-ATTTCCATCCCAAACCCC-3') and antisense (5'-TCACCCATTCTTAGCCCATTTC-3') primers (Li et al. 1997). Both WT and $D$ alleles were detected in Chinese breeds, but only the WT allele was detected in WC, American Landrace, Yorkshire and Berkshire pigs (Table 1).

Linkage analysis was conducted on 104 pigs in the USDA-MARC reference population (WC, Duroc, MS, Fengjing and Minzhu crosses, Rohrer et al. 1994b). This analysis employed the described marker to determine $D$ and $W T$ alleles, a microsatellite (Tn) located $4 \mathrm{~kb} 5^{\prime}$ to the TATA (Ellegren 1993) and a PCR-RFLP located within the first intron of FSHB (Rohrer et al. 1994a). No recombinants were detected between these three markers.

In males heterozygous for the FSHB alleles, expression levels of these two were estimated by RPA specific for FSHB and normalized by $\beta$-actin mRNA. The $D$ allele was expressed at similar $(P>0.05)$ intensity as the Wt allele within three independent groups of males. Within each group, expression of the total of the two alleles was positively correlated with pituitary and plasma FSH concentrations $(P<0 \cdot 01)$.

Sequencing of full-length cDNA's of the $D$ allele from two unrelated boars, including boar no. 8, revealed that both animals had six additional nucleotide differences in the 3 '-UTR compared to the WT allele (Hirai et al. 1990). In the coding region, a transitional mutation from ATC to ATT was detected for isoleucine at codon 16 (GenBank accession no. AF134151).

In summary, we identified a $F S H B$ allele in Chinese breeds of pigs that had a 11-bp deletion in the 3 '-UTR plus a silent change in the coding region. The $W T$ allele was present in all breeds examined, but $D$ allele was detected only in Chinese breeds. Furthermore, we demonstrated that $D$ allele was expressed at a level similar to

(A)

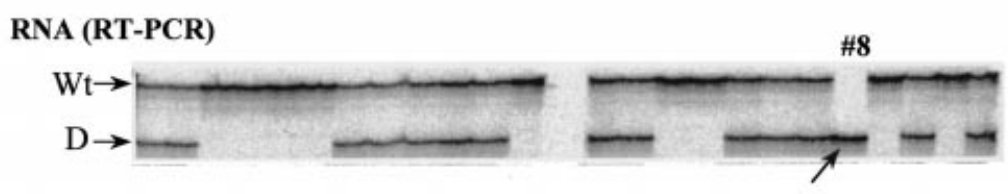

(B)

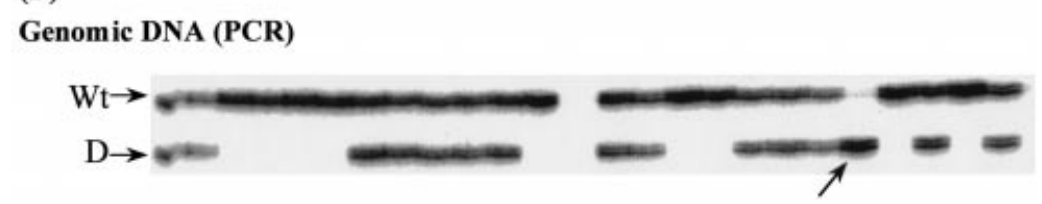

Fig. 1. Distribution of the $D$ allele for $F S H B$ in $24 \mathrm{MS} \times$ WC crossbred males. cDNA reverse-transcribed from RNA (A) or DNA (B) was amplified with FSHB specific primers. Among $24 \mathrm{MS} \times$ WC crossbred males screened by RTPCR and PCR, only boar no. 8 was homozygous for the $D$ allele. 
$W T$ allele in anterior pituitary glands of heterozygous males.

Presence of $D$ allele at a high frequency in Chinese breeds and its absence in US breeds, especially Yorkshire and Berkshire, are puzzling. These two breeds, during their early development in late seventeenth and early eighteenth centuries, included crosses with Chinese pigs from the south region of China where Xiang and Hainan pigs were formed (Zhang et al. 1983; Jones 1998). Today the D allele exists in Xiang and Hainan pigs; therefore, we predict it was present in ancestors of these breeds. If so, why was this allele not transmitted into the European breeds when crossed with Chinese pigs? To date, no phenotypic traits are associated with the $D$ allele. Li et al. (1998b) reported an association between an FSHB linked RFLP and litter size in Chinese pigs, but these findings conflict with our larger study of MS $\times$ WC gilts, in which no QTL for the components of litter size was identified on chromosome 2 where the FSHB gene resides (Rohrer et al. 1999).

\section{Acknowledgements}

We thank MARC Swine operations personnel for care of the animals, USDA/NIH for antiovine FSH (AFP-C5288113), ovine FSH for iodination and the porcine FSH reference (USDA, B-1) preparation, S. Hassler, R. Lee and D. Griess for technical assistance, and N. and K. Biensen for collection of tissue from Berkshire pigs.

\section{References}

Chirgwin J., Przybyla A., MacDonald R. \& Rutter W.J. (1979) Isolation of biological active ribonucleic acid from sources enrich in ribonuclease. Biochemistry 18, 5294-9.
Ellegren H. (1993) Variable SINE 3' poly (A) sequences: an abundant class of genetic markers in the pig genome. Mammalian Genome 4, 429-34.

Hirai T., Takikawa H. \& Kato Y. (1990) The gene for the beta subunit of porcine FSH: absence of consensus oestrogen-responsive element and presence of retroposons. Journal of Molecular Endocrinology 5, 147-58.

Jones G.F. (1998) Genetic aspects of domestication, common breeds and their origin. In: The Genetics of the Pig (ed. by M.F. Rothchild \& A. Ruvinsky), pp. 17-50. CAB International, Oxon, UK.

Li M.D., Macdonald G.J. \& Ford J.J. (1997) Breed differences in expression of inhibin/activin subunits in porcine anterior pituitary glands. Endocrinology 138, 712-8.

Li M.D., Macdonald G.J., Wise T.H. \& Ford J.J. (1998a) Positive association between expression of follicle stimulating hormone-beta and activin B-subunit genes in boars. Biology of Reproduction 59, 978-82.

Li N., Zhao Y.F., Xiao L. et al. (1998b) Candidate gene approach for identification of genetic loci controlling litter size in swine. Proceedings of the Sixth World Congress on Genetics Applied Livestock Production 26, 183-6.

Rohrer G.A., Alexander L.J., Keele J.W., Smith T.P. \& Beattie C.W. (1994a) A microsatellite linkage map of the porcine genome. Genetics 136, 231-45.

Rohrer G.L., Alexander L.J. \& Beattie C.W. (1994b) Mapping the subunit of follicle stimulating hormone (FSH) in the porcine genome. Mammalian Genome 5, 315-7.

Rohrer G.A., Ford J.J., Wise T.H., Vallet J.L. \& Christenson R.K. (1999) Identification of quantitative trait loci affecting female reproductive traits in a multigeneration Meishan-White composite swine population. Journal of Animal Science 77, 1385-91.

Zanella E.L., Ford J.J., Wise T. \& Hamernik D.L. (1996) Pituitary relationship of gonadotropins and mRNA for gonadotropin subunits in white composite and Meishan boars. Biology of Reproduction 54, 154-9.

Zhang W.C., Wu J.S. \& Rempel W.E. (1983) Some performance characteristics of prolific breeds of pigs in China. Livestock Production Science 10, 59-68. 